\title{
Toward Effective Stakeholder Dialogue
}

Article in Business and Society Review · May 2003

DOI: 10.1111/1467-8594.00161

CITATIONS

167

2 authors:

Muel Kaptein

Rotterdam School of Management

125 PUBLICATIONS 3,550 CITATIONS

SEE PROFILE

\section{READS}

1,578

Rob van Tulder

Erasmus University Rotterdam

153 PUBLICATIONS 3,337 CITATIONS

SEE PROFILE

Some of the authors of this publication are also working on these related projects:

Project $\quad$ Modeling neutralization techniques View project

Special issue call for papers from critical perspectives on international busines: Working towards the Sustainable Development Goals in earnest - critical international business perspectives on designing better interventionss View project 


\title{
Toward Effective Stakeholder Dialogue
}

\author{
MUEL KAPTEIN AND ROB VAN TULDER
}

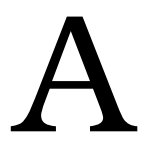

company's license to operate and grow is no longer seen exclusively in terms of maximizing profits. Embedding an organization in society-in a sustainable manner-has become a condition for continuity and growth. Sustainable development requires that a company's performance be valued positively by the stakeholders, in financial, environmental, and social terms. ${ }^{1}$ The financial bottom line moves aside for the triple bottom line, ${ }^{2}$ in which profits are linked to environmental (planet) and social (people) value.

To an increasing extent, both primary and secondary stakeholders are calling companies to account directly for their triple bottom line. "Civil society is demanding greater accountability and transparency from business" according to the World Resources Institute and the World Business Council for Sustainable Development. ${ }^{3}$ The number of international NGOs registered by the Union of International Associations has more than doubled since 1985, and now amounts to $40,000 .{ }^{4}$ However, the public's impression of how companies deal with issues of sustainability does not always seem to be positive. Research by CSR Europe in 2000 revealed that half the European population believes that insufficient attention is paid to socially responsible business practice. A study by the Conference Board showed that half the U.S. population said that, when making recent purchases, they had taken the social performance of the company into consideration. ${ }^{5}$ In most countries, the government

Muel Kaptein is Professor of Business Ethics and Integrity Management; Rob van Tulder is Professor of International Business-Society Management. Both authors are at the Rotterdam School of Management, Erasmus University, Rotterdam. 
adopts a more wait-and-see attitude. In particular, a growing group of shareholders and investors attaches significant importance to the sustainability of a company. ${ }^{6}$ If this is not for ethical reasons, then it is because the same shareholder is also part of the society and benefits (indirectly) from sustainable development. And if this perspective is also missing, then there is also the insight that sustainable business practice is beneficial for the profitability of the company and therefore of direct importance to the shareholders. ${ }^{7}$ Research by the Social Investment Fund revealed that the market for sustainable investment increased tenfold in the 1990 s. $^{8}$ At the end of the 1990s, this market amounted for more than USD 2 trillion. In view of the interests in and attention being paid to sustainability, can it be assumed that companies will create new forms of self-regulation and sustainability independently and autonomously, or is outside help required?

In this article, we want to examine how, in addition to-and in interaction with-voluntary business codes and sustainability reporting, a stakeholder dialogue can contribute to effective selfregulation. First, we look at the advent of stakeholder dialogue in the context of the increasing use of company codes and sustainability reporting. We then define the characteristics of stakeholder dialogue and examine what conditions are needed for this to progress effectively. Next, we look at the possible outcomes; and, finally, conclude with an initial analysis of four companies that developed four different forms of stakeholder dialogue.

\section{CODES AND REPORTS}

Some companies are rather cautious about extending their responsibilities in line with the triple bottom line. Other companies, however, are quite progressive and apply this development to, for example, their competitive strategy and personnel policy. The number of companies with a company code is growing. At the end of 2001 , at least 58 of the 100 largest companies in the world had their own code of conduct. In such a document, a company sets out its own responsibilities with respect to its stakeholders and/or the norms and values on the basis of which it operates. To give an example, Nestlé-a company that has been strongly affected by a conflict with its stakeholders about the sale of baby milk in the 
1980s - states the following in the introduction to its business principles:

Nestlé carries out its global social responsibility, firstly, by taking a long-term approach to strategic decision making which recognizes the interests of our consumers, shareholders, business partners, and the world-wide economies in which we operate. Secondly, our responsibilities and values are reflected by the commitment of management and employees at all levels, to the following specific Corporate Business Principles, which define standards of behavior for all companies in the Nestlé Group, and are intended to complement applicable legislation and international recommendations.

When companies do not develop their own proper codes for this purpose, influential nongovernmental social organizations can develop initiatives themselves, without the government having to draw up laws. An interesting example is the international soccer association FIFA, which was the primary stakeholder in organizing the 1998 World Cup. FIFA drew up a code of conduct for participating companies that stated, for example, that footballs manufactured using child labor were not allowed. This standpoint reinforced the position of those companies that had already drawn up their own code of conduct (such as Nike). ${ }^{9}$ However, in practice, this was also only the beginning of a dialogue: for the 2002 World Cup, social organizations such as the Clean Clothes Campaign raised the issue-with some justification-of whether the FIFA code of conduct was effective.

Developing a code of conduct is frequently the first step toward a sustainable company. ${ }^{10}$ The code is an instrument that can be used to anchor and increase the employees' understanding of the company responsibilities. ${ }^{11} \mathrm{~A}$ code also stimulates the organization to bring its systems and processes in line with what is stated in the code. However, a code is also primarily a document in which the context and foundation are provided so that discussions can take place internally about the company's own responsibilities and the dilemmas that are encountered in the course of day-to-day activities.

For the external stakeholders, the code also functions as a test for the company's conduct and the grounds on which stakeholders can hold the company accountable. Sooner or later, the stakeholders 
TABLE 1 Social Issues Addressed in the Sustainability Reports of the Global Fortune Top 250

$\begin{array}{ll}\text { Community involvement } & 97 \% \\ \text { Health and safety } & 91 \% \\ \text { Equal opportunity/workforce diversity } & 88 \% \\ \text { Employee satisfaction } & 67 \% \\ \text { Human rights in general } & 55 \% \\ \text { Supplier relations } & 39 \% \\ \text { Child labor } & 36 \% \\ \text { Freedom of association } & 27 \% \\ \text { Fair trade/international development } & 18 \% \\ \text { Corruption } & 15 \%\end{array}$

will call the company to account for the extent to which the code is actually complied with. This is what happened at Shell in 1997: the English general meeting of shareholders asked the management to report on the degree to which the Shell Business Principles were being followed within the entire organization.

In the past, companies were able to satisfy stakeholders' questions with the simple response of "trust me." However, nowadays, stakeholders are demanding, in unison, "show me." Sustainability Reporting is thus making its entrance as an integrated annual report for the triple bottom line. Shell, British Telecom, ING Bank, Volkswagen, the Body Shop, and BP Amoco have all published such a report for one or more years. A sustainability report allows companies to account for their performance on the triple bottom line and set out their sustainability policy in the near future. In 2001, 45 percent of the Global Fortune Top 250 has published an environmental, social, or sustainability report. ${ }^{12}$ Table 1 provides a summary of the social issues addressed in the sustainability reports. However, in practice, it is clear that sustainability reporting and codes of conduct have a long way to go with respect to objective external verification. In this vein, only 29 percent of the companies actually have their codes and reports verified by external parties. ${ }^{13}$ In reality, sustainability reports contain little hard data and are often anecdotal. Most of these reports do not state how the information was gathered, and only rarely are objectives included in the reports. ${ }^{14}$ These reports are actually quite "soft." For example, there is generally only isolated information provided in the categories of People, Planet, and Profit. There is very little integrated information, 
TABLE 2 Best Practices Worldwide ${ }^{15}$

\begin{tabular}{lll}
\hline Baxter & General Motors & Procter \& Gamble \\
The Body Shop & Monsanto & Rio Tinto \\
BP Amoco & Nestlé & Shell \\
Bristol-Myers Squibb & Norsk Hydro & Sun Company \\
British Airways & Novo Nordisk & Tokyo Electric Power \\
Dupont Canada & Ontario Power & Volvo \\
Electrolux & Generation & \\
& Polaroid &
\end{tabular}

even though this is exactly the type of added value that should be offered by a sustainability report.

Lists of "best practices" are an important tool in negotiating about the further elaboration of sustainability reports. If we combine several of the most well known lists, it results in 20 companies (see Table 2) that can be characterized as providing "best practices" in the field of sustainability reporting.

The following patterns can be identified:

- Many companies have a high "icon" rating and a direct relationship with the markets for end consumers (such as General Motors, Polaroid, Shell, BP, Body Shop, British Airways); there are very few producers of intermediate products included in this list.

- During the 1980s and 1990s, many best practice companies have had a major public conflict with important stakeholders on a number of specific social issues (Shell, Nestlé, Rio Tinto, Monsanto, Dupont, General Motors, Novo Nordisk).

- In cases where neither the image for the consumers nor the issue itself was a factor, it appears that best practices can be found in small countries (Electrolux, Norsk Hydro, Volvo, Ontario Power Generation) where there is generally stricter legislation on reporting (in particular environmental and social reporting), and where there are also traditionally corporatist consultation structures that facilitate structured social discussions about issues between representatives of employers, employees, and the state.

To an increasing extent, the best practices in the area of sustainability reporting contain a description of the dilemmas confronting the organization. The main issue for sustainable development 
concerns primarily the choices companies make between the conflicting interests of stakeholders. ${ }^{16}$ A company shows what it stands for by its behavior in situations where it must choose, for example, between making large-scale environmental investments and short-term profits, between mass layoffs and safeguarding profitability requirements, or between respecting human rights and relocating production facilities to low-wage countries. It is precisely how companies deal with situations where they are confronted with an overload of legitimate expectations, which reveals their sustainability as a company.

\section{STAKEHOLDER DIALOGUE}

Because it is impossible to satisfy every interest of every stakeholder, it is important that stakeholders are confident that companies are dealing with their interests with the necessary care. Stakeholder trust in a company can be achieved in particular by involving them in the dilemmas the company is faced with. This can be done in two ways: by informing stakeholders, for example, by means of an annual report, and also by communicating with each other. In this context, the stakeholder dialogue made its entrance in the mid-1990s. It was first initiated by NGOs like the World Wildlife Fund (such as in the context of the Marine Stewardship Council), but also to an increasing degree later by individual companies, like the Body Shop, and coalitions of companies, such as the World Business Council for Sustainable Development. ${ }^{17}$

In the dialogue with stakeholders (both primary and secondary) opinions are exchanged, (future) interests and expectations are discussed, and standards are developed with respect to business practice. Ultimately, a proper dialogue not only enhances a company's sensitivity to its environment, ${ }^{18}$ but also increases the environment's understanding of the dilemmas facing the organization. ${ }^{19}$ "Stakeholder dialogue is a powerful catalyst for change. It promotes greater transparency, information sharing and inspires society to work together," according to the World Business Council for Sustainable Development. ${ }^{20}$ Reporting gives structure to stakeholder dialogue. Reports allow checks to be carried out into whether all the relevant perspectives are involved in the dialogue. Reporting also allows each stakeholder involved in the dialogue to be informed 
about the discussions that take place with other stakeholders. By means of reports, the stakeholders who are not present are informed about how the company puts its responsibilities into practice, and, insofar as relevant, how the company is dealing with their rights and interests. Especially in cases where reports are accompanied by an invitation to respond (as Shell expressly does), this will lead to greater stakeholder involvement in the dialogue and therefore with the company. In this sense, reporting supports stakeholder dialogue, and vice versa. Stakeholder dialogue is mentioned in 36 percent of nonfinancial annual reports. ${ }^{21}$

In many cases, companies are already holding discussions with stakeholders, such as employee representatives, government institutions, consumer organizations, and those living in the surrounding area. By including these as part of the (strategic) stakeholder dialogue, these discussions can take place in a more structured and targeted manner. In this respect, stakeholder dialogue is neither a highly labor intensive nor an expensive process. By means of reporting, coherence is created in the stakeholder discussions, which provides value for the company and the stakeholders themselves.

A stakeholder dialogue is also appropriate for developing key performance indicators (KPIs). Proper KPIs have to be developed for the reporting on and internal management of the sustainable company. This provides the essential translation of ambitions and responsibilities contained in the code into measurable objectives for management and staff, as well as external stakeholders. The development of KPIs for sustainable business practice is still in its infancy. A number of standards, such as the GRI, SA 8,000, and AA 1,000 , have recently appeared. However, for the time being, these standards highlight only one or a few aspects of sustainable business practice. A crystallized and balanced set of KPIs is still lacking at present. Perhaps this is not such a bad thing at the moment: the absence of such a set of KPIs is a greater stimulus to companies to find out themselves, in consultation with the stakeholders, what elements demonstrate their company's sustainability.

In a stakeholder dialogue the relationship between the company and the stakeholders can shift from one of confrontation and competition to one of consultation and cooperation. The call of "trust me" and "show me" makes way for one of "involve me," "join me," or "engage me." Table 3 highlights a number of differences between conducting a debate with stakeholders and engaging them in a dialogue. 
TABLE 3 Stakeholder Debate Versus Stakeholder Dialogue

Stakeholder Debate

1. Competition with a single winner or only losers (either-or thinking)

2. Egocentric where the other party is a threat or a means to personal profit

3. Putting yourself in a better light

4. Speaking, to which others have to listen

5. Influencing

6. Confronting, combative and destructive, whereby the weaknesses and wrongs of the other party are sought out and the similarities are negated

7. A closed and defensive attitude because you personally know the truth

8. Taking and keeping

9. Divide and rule

10. Separate/isolated responsibilities
Stakeholder Dialogue

$\rightarrow \rightarrow \rightarrow$ Cooperation where everyone is a winner (and-and thinking)

$\rightarrow \rightarrow \rightarrow$ Empathetic where the other party is an opportunity and represents an intrinsic interest

$\begin{array}{ll}\rightarrow \rightarrow \rightarrow & \text { Being yourself } \\ \rightarrow \rightarrow \rightarrow & \text { Listening to others before }\end{array}$ speaking yourself

$\rightarrow \rightarrow \rightarrow$ Convincing

$\rightarrow \rightarrow \rightarrow$ Constructive and, from a point of mutual understanding and respect, looking for similarities from which to consider the differences

$\rightarrow \rightarrow \rightarrow$ A vulnerable attitude because there are many truths and where parties are open to criticism about their own performance and they can use this to learn from each other

$\rightarrow \rightarrow \rightarrow$ Giving and receiving

$\rightarrow \rightarrow \rightarrow$ Share and serve

$\rightarrow \rightarrow \rightarrow$ Shared responsibilities

Stakeholder dialogue is a structured interactive and proactive process aimed at creating sustainable strategies. Entering into a stakeholder dialogue is not an exercise without value. With their choice for a stakeholder dialogue, companies express respect for stakeholders to listen to their contribution and demonstrate the commitment to learn from each other. ${ }^{22}$ In this context, the medium alone is already an important message.

\section{PRECONDITIONS}

Stakeholder dialogue is no universal remedy. Talking does not solve everything. In some instances, other avenues will be more obvious, such as government regulation, public opinion, and own initiative. 
TABLE 4 Ten Preconditions for an Effective Stakeholder Dialogue

1. To know and be understood

2. Trust and reliability

3. Clear rules for the dialogue

4. A coherent vision on the dialogue

5. Dialogue skills

6. Expertise in the subject matter

7. Clear dialogue structure

8. Valid information as basis

9. Consecutive meetings

10. Feedback of results

Not everything needs to be discussed: many issues will remain internal issues. Furthermore, a stakeholder dialogue is no substitute for a company's own responsibilities; the company remains responsible for its own policy and conduct. A company is, after all, not a representative democracy. Stakeholders must accept that this involves making choices and reaching compromises. Stakeholder dialogue, therefore, does not imply that stakeholders have the right to be involved in all decisions, that all stakeholder expectations have to be met, or that the company can hide behind the stakeholder dialogue. Thus, the success of a stakeholder dialogue depends on a range of factors. ${ }^{23}$ At this point, we would like to describe a number of important criteria (see Table 4) for a stakeholder dialogue (based also on the experience we have as facilitators of many stakeholder dialogues).

1. To know and be understood. The parties must know each other and know their common areas of interest. After all, without a discussion partner, there can be no dialogue. This requires that organizations specifically anticipate who will have to bear which consequences of the company's actions (in both the short and the long term, and both the direct and indirect consequences), and who will act as representative of specific social interests.

2. Trust and reliability. A stakeholder dialogue is doomed to failure unless there is a certain level of trust in the integrity of the other party and the value of the dialogue. Of course, a constructive dialogue increases the level of trust; at the same 
time, however, in the absence of any form of trust whatsoever, the dialogue will never get off the ground and, consequently, the level of trust also cannot increase. This means that parties can only allow themselves an open and vulnerable attitude if the other party is also prepared to do this as well.

3. Clear rules for the dialogue. Despite the fact that there may be a high level of trust between the discussion partners, it is advisable to agree to procedures with respect to, for example, how to deal with confidential information and the way in which the parties involved report the meeting to their own constituents and the media. It is fatal for a confidential discussion if, some days later, confidential information becomes public or if the other party is publicly discredited. The chance of agreements being violated, in particular, increases as the balance of power between the parties becomes more unequal. When entering into a dialogue, both parties effectively place restrictions upon themselves.

4. A coherent vision on stakeholder engagement. A discussion with a stakeholder normally takes place within the framework of a series of discussions. It is important that the stakeholder is aware of this. For the company, this implies that it should have a vision on the stakeholder discussions as a whole. What is the underlying philosophy? What is the ultimate aim? Which criteria are applied in the selection of stakeholders for a dialogue, in the manner and frequency with which the meetings are held? The company should guard against being too indiscriminate in this respect, and create a balance between accepting invitations from stakeholders to attend meetings and, alternatively, personally inviting stakeholders for meetings.

5. Dialogue skills. The parties must possess the skills for taking part in a dialogue. The characteristics of a dialogue, as summarized in Table 3, demand a totally different repertoire and communication style than taking part in a debate.

6. Expertise in the subject matter. A good dialogue demands good preparation. Conducting a proper dialogue requires the availability of expert knowledge of the subject matter to understand what both you personally and the other party are talking about. 
7. Clear dialogue structure. To promote a good dialogue, it is desirable that the parties have clear and explicit expectations about the possibilities and limitations of the dialogue. Likewise, it also requires a clear agenda for the meetings and careful recording of the meeting and the follow-up agreements.

8. Valid information as basis. The dialogue is usually based on the information the parties present about the actual situation. This results in a natural inclination to manipulate the facts or to present only those facts that fit in with one's own agenda. It is therefore important that the facts presented are beyond any doubt, which is why an external party will sometimes scrutinize the information in advance to assess its validity. It is also increasingly the practice that accountants verify sustainability reports.

9. Successive meetings. A dialogue cannot be an on-off event-at the very least, there will have to be feedback on what has been agreed. Indeed, a greater number of meetings creates the opportunity for parties to get to know each other better. The World Business Council for Sustainable Development expresses the importance of this as follows: "Aim to build joint ownership for actions towards change to be taken following the dialogue."24

10. The feedback of results. It is desirable that the discussion partners do not act in isolation from those they are representing. This may create the situation of one of the parties being called back or overruled afterwards, as a result of which agreements made during the dialogue cannot be implemented. There is nothing as fatal as the management or directors having to say, after three constructive meetings, that they cannot, with hindsight, support the conclusions. Or if, with the departure of one of the people involved, the successor sees nothing in the results of the earlier meetings. Mutual trust also implies that parties can rely on the fact that the other party properly represents the interests and views of its constituents.

\section{THE BUSINESS CASE}

What results can an effective stakeholder dialogue achieve? What is the business case? ${ }^{25}$ 
1. To identify trends and future issues at an early stage and to prioritize these.

2. To gain insight into the stakeholders' appreciation for the organization and the evaluation of the current performance.

3. To allow the organization and stakeholders to gain a better understanding of each other's interests and dilemmas, and broader support for the decisions companies make.

4. To resolve specific tensions in the relationship with stakeholders.

5. To gather suggestions and ideas for improving the company's performance in the social area, as well as KPIs for the sustainability report.

6. To increase sensitivity within the organization for the stakeholders' expectations and to heighten the sense of responsibility for social issues.

7. To create a greater mutual buffer of trust, whereby possible problems can be dealt with more effectively.

8. To avoid incidents that receive wide public and media attention.

9. To create a basis for joint projects, alliances, and partnerships.

\section{ISSUES TO CONSIDER WHEN SETTING UP A DIALOGUE}

It is important that a stakeholder dialogue is conducted in a well-considered manner. Relevant questions for an organization to consider include:

- How do we clarify for ourselves what the specific objectives of the stakeholder dialogue are?

- How do we decide which stakeholders we are going to talk to?

- How do we determine the topics for discussion?

- Who will represent the organization in the meetings?

- How can we determine the order of the meetings?

- How often should the meetings take place?

- How do we avoid leaving out stakeholders, as a result of which they may feel excluded and cause a big fuss? 
- How do we retain our freedom to make decisions and carry our responsibility for these?

- How do we avoid stakeholders abusing the trust we vest in them and the information we share with them?

- How do we avoid stakeholders developing the feeling, also in hindsight, that they are being or have been abused?

- How can we learn the most from the meetings?

- How do we avoid creating overly high expectations among the stakeholders about the content and follow-up of the stakeholder dialogue?

- How do we prevent a stakeholder dialogue from becoming a timeconsuming exercise?

- How can the dialogue be embedded in the management systems and the sustainability report that may be published?

- How can we know that the stakeholder dialogue satisfies the wishes of the stakeholders?

It is desirable that organizations ask themselves these questions as early as possible in the process (preferably before starting the dialogue). Practical experience has shown that insufficient attention for and inadequate responses to these issues can lead to a situation in which, for instance:

- Stakeholders feel ignored.

- Stakeholders feel abused.

- The meetings become a repetition of sets.

- The internal support for the meetings crumbles.

- Confidential information is misused.

\section{FOUR CASES}

The way in which a stakeholder dialogue is shaped depends, among other things, on a company's response to the questions above. There is no "one best way" to conduct stakeholder dialogue ${ }^{26}$ it will be defined by the extent of urgency, the legitimacy and power of the stakeholders and the issues that arise,${ }^{27}$ the stakeholders' willingness to cooperate, ${ }^{28}$ and the competencies of the company. At this 
point, we would like to consider four examples of companies involved in a stakeholder dialogue. It will become clear that each one of these companies applies a different form.

\section{Case 1. A Broad, Proactive Dialogue}

In the spring of 2001, a European telecommunications company started a stakeholder dialogue. This move was prompted by its recently published company code of conduct. The code of conduct described the company's responsibility with respect to the different stakeholder parties. The aim of the code was to stem the tide of criticism from the stakeholders concerning the company's performance. The code defined the ambitions the company wants to strive for. The aim of the stakeholder dialogue, in the first instance, was to inform the stakeholders about the new code and the motives behind its introduction. In addition, the company wanted to invite stakeholders to indicate to what extent there was a discrepancy between the ambitions and responsibilities contained in the code and the current practice, and, if such a discrepancy did exist, to invite stakeholders to contribute suggestions and ideas. Thus, the company aimed to increase support among stakeholders, as well as the performance level of the company itself.

To prepare for the dialogue, a list of relevant stakeholders was drawn up. In addition to the list of stakeholders obtainable from the Public Affairs department, the directors of internal departments, members of the Management Board, and directors of the business units were invited to make their own additions. Likewise, media sources were consulted to find stakeholders who had been critical of the company in the past. This finally produced a list of almost one hundred stakeholder groups. Because it was not possible to talk to all of these groups in the short term, the list was divided into three categories: (1) urgent stakeholders with whom it was essential to hold discussions within six months, (2) less urgent stakeholders who could be invited for a meeting during a second round, and (3) stakeholders who would be informed in writing of the code and with whom the initiative would then lie for making an appointment for a meeting.

It was agreed that not only a member of the Public Affairs department would represent the company at the meetings, but also at 
least one member of staff from the department that saw the stakeholder in question as falling within its remit, and preferably also a line manager. Such a delegation would not only send out a clear signal to the stakeholder that the meetings were being taken very seriously, but also stimulate the sensitivity of the relevant officer and line manager for the expectations of the stakeholders. Eventually, Public Affairs fulfilled "only" a facilitating role.

A meeting was held with senior management to prepare for the dialogue. The sixty managers were invited for an afternoon to come and put themselves in the stakeholders' shoes and critically examine their own company. Then, as the stakeholder, they held a discussion with the executives who would actually be holding the dialogue with the stakeholder in question. This process allowed the executives to prepare for the actual dialogue. In addition, after a while, the critical points identified could be used to determine the extent to which either the senior management had a proper image of their own company or the stakeholders viewed the company completely differently. Additionally, the Public Affairs department staff members received training in dialogue skills.

In the first six months, separate discussions were held with thirty stakeholder groups. After an appointment was made by phone with the stakeholder, he or she was informed in advance about the rules the company would follow in the context of the dialogue. An important element of this concerned the confidentiality of the shared information. Confidential reports were drawn up of the discussions and submitted to the stakeholder in question for approval. At the end of each discussion, the session was evaluated. Most of the stakeholders experienced the discussions as positive and were hopeful about a follow-up. In general, the management also experienced the discussions as valuable.

Every six months, the line management receives a report about the outcome of the discussions. In particular, the problem areas and stakeholder suggestions receive a prominent place in these reports. Some stakeholders are also invited to set out their vision in the staff magazine, to increase the sensitivity of the personnel toward these stakeholder interests. The stakeholder owner is responsible for monitoring the follow-up to the agreements and the relevant feedback to the management and the stakeholders themselves. 


\section{Case 2. Stakeholder Panel}

In the late 1990s, a big international chemical company began a stakeholder dialogue in response to strong criticism of its decisions by the environmental movement. The management had also met with opposition from its personnel with regard to its environmentunfriendly policies. Because the management of the company was somewhat shocked by such unexpected criticism, it examined how it could better gain knowledge of the opinions and expectations inside the company concerning the environment. In addition to studies re-evaluating the image, trend analyses, and scenario planning, a decision was made to enter into dialogue with stakeholders. That is not to say that the company had not communicated with its surroundings before this point, but rather that it was now adopting a more open and vulnerable position. The most critical (determined on the basis of the intensity of the response) and the largest (based on the number of members) NGOs were invited for environmental workshops in the form of round-table meetings. During these workshops, which were held in many countries by the local subsidiary, a large number of participants were invited to give reasons why, in their opinion, the company had failed, what apparently fundamentally was wrong with the way the organization dealt with its environment, and what the company could do in the future to avoid such incidents. The workshops led to a revised environmental policy and plans to deal more openly with the stakeholders. To this end, a sustainability report has been published each year since this process took place. Recognition and support by NGOs for the company's policy increased: several years later, the company is regularly in the media and it is regarded by the NGOs as a trend-setter.

\section{Case 3. Selective Reactive Stakeholder Dialogue}

In the late 1990s, the main office of a transport company held several discussions with environmental groups. The reason for this was these groups' dissatisfaction with the quality of the environmental annual report of this company. The company had difficulty understanding the criticism in view of the sincere intentions of the environmental report. However, the company found it important to convince the groups of its intentions and to evaluate the extent to which the environmental groups had suggestions to improve the 
company's report in the coming years. A conscious choice was made not to enter into dialogue with other stakeholders. Additionally, the discussions with the environmental groups were not publicized, as the company wanted to first examine the results of these discussions. All in all, the environmental manager, who conducted these discussions, did not wish to be too ambitious or act too hastily. Over a period of six months several discussions were held with each of the environmental groups separately. And indeed, the environmental groups offered valuable suggestions for improvement of the environmental report. According to the environment manager, the consultation process appeared to increase the environmental groups' support for the company's environmental policy. However, there was no substantiation of this by asking the environmental groups for their opinion about the discussions. But mention was made in the environmental annual report of the discussions, without going into detail on the results. In anticipation of the development of the growing use of sustainability annual reports by the business community, the environment manager proposed expanding the environmental report to include a social annual report and consequently to expand the stakeholder dialogue to the social discussion partners.

\section{Case 4. Defensive Dialogue}

A financial services firm was confronted in the media with allegations from pressure groups. According to these groups, the bank allegedly made loans to socially undesirable projects. To reinforce their message, the group made an appeal to account holders to close their accounts. Even though the effect was minimal the campaign received the necessary media attention. Furthermore, this made it clear to the bank that it was quite powerless against such allegations. Although the bank had a clear and well-thought-out lending policy, it became difficult to clearly communicate this while in the midst of a public debate. It seemed that appearances were against the financial institution, which made it easy prey for pressure groups. Because the image of a bank is made or destroyed by its integrity and reliability, the bank decided to hold discussions with these pressure groups. The Public Affairs department received the activists several times at its office. The discussions resulted in a joint agreement in which the financial institution declared that it 
would consider the possible social consequences of requests for large loans in its decision-making. At the same time, the pressure groups admitted that the bank was not primarily responsible for how the loans are spent. Consequently, it was agreed that, in the case of a supposed breach of the agreement, both parties would first talk to one another before calling in the media. More than one year after this agreement was made, the pressure groups and the financial institution have not considered it necessary to hold such a discussion.

TABLE 5 Dimensions of Stakeholder Dialogue

\begin{tabular}{|c|c|c|c|c|}
\hline & Telecom & Chemical & Transport & $\begin{array}{l}\text { Financial- } \\
\text { service }\end{array}$ \\
\hline $\begin{array}{l}\text { Type of issue (social } \\
\text { and/or } \\
\text { environmental) }\end{array}$ & $\begin{array}{l}\text { Social and } \\
\text { environmental }\end{array}$ & Environmental & Environmental & Social \\
\hline $\begin{array}{l}\text { Number of } \\
\text { stakeholders } \\
\text { involved in the } \\
\text { dialogue }\end{array}$ & Many & Many & One & One \\
\hline $\begin{array}{l}\text { Frequency of } \\
\text { conversations }\end{array}$ & Frequent & Regular & Sometimes & A few times \\
\hline $\begin{array}{l}\text { Number of issues per } \\
\text { conversation }\end{array}$ & $\begin{array}{l}\text { One or } \\
\text { a few }\end{array}$ & Few & Many & One \\
\hline $\begin{array}{l}\text { Number of } \\
\text { stakeholders per } \\
\text { conversation }\end{array}$ & $\begin{array}{l}\text { One } \\
\text { stakeholder }\end{array}$ & $\begin{array}{l}\text { A few } \\
\text { stakeholders }\end{array}$ & $\begin{array}{l}\text { One } \\
\text { stakeholder }\end{array}$ & $\begin{array}{l}\text { A few } \\
\text { stakeholders }\end{array}$ \\
\hline $\begin{array}{l}\text { Orientation toward } \\
\text { problems (identifying } \\
\text { problem and/or } \\
\text { problem solving) }\end{array}$ & $\begin{array}{l}\text { Identifying } \\
\text { problems }\end{array}$ & $\begin{array}{l}\text { Problem } \\
\text { solving }\end{array}$ & $\begin{array}{l}\text { Identifying } \\
\text { problems / } \\
\text { problem } \\
\text { solving }\end{array}$ & $\begin{array}{l}\text { Problem } \\
\text { solving }\end{array}$ \\
\hline $\begin{array}{l}\text { Orientation toward } \\
\text { time (prospective } \\
\text { and/or retrospective) }\end{array}$ & $\begin{array}{l}\text { Particularly } \\
\text { prospective }\end{array}$ & $\begin{array}{l}\text { Prospective/ } \\
\text { retrospective }\end{array}$ & $\begin{array}{l}\text { Prospective/ } \\
\text { retrospective }\end{array}$ & $\begin{array}{l}\text { Particularly } \\
\text { retrospective }\end{array}$ \\
\hline $\begin{array}{l}\text { Participants of the } \\
\text { organization (support } \\
\text { management, } \\
\text { operational } \\
\text { management and/or } \\
\text { employees) }\end{array}$ & $\begin{array}{l}\text { Support } \\
\text { management } \\
\text { and operational } \\
\text { management }\end{array}$ & $\begin{array}{l}\text { Support } \\
\text { management }\end{array}$ & $\begin{array}{l}\text { Support } \\
\text { management }\end{array}$ & $\begin{array}{l}\text { Support } \\
\text { management }\end{array}$ \\
\hline $\begin{array}{l}\text { Organizational level } \\
\text { (head office and/or } \\
\text { local) }\end{array}$ & Head office & Local & Head office & $\begin{array}{l}\text { Head office } \\
\text { and local }\end{array}$ \\
\hline $\begin{array}{l}\text { Monitoring of } \\
\text { dialogue quality }\end{array}$ & Somewhat & Somewhat & Somewhat & Somewhat \\
\hline $\begin{array}{l}\text { Inclusion in annual } \\
\text { report }\end{array}$ & No & Largely & Largely & No \\
\hline
\end{tabular}


Table 5 shows that, in all four cases, the discussions are periodic, mainly general management is involved, and no monitoring of the quality of the dialogue takes place. Mention of the dialogue is not always included in the annual report, which is an indication of the relatively poor embedding of stakeholder dialogues in companies' general business strategy and the associated approach to external communications. A more proactive dialogue (Telecom) differs from a reactive dialogue (Transport and Financial), in that the discussions are more prospective, they take an inventory of the problem, and not only is general (central) management involved in the dialogue. As far as can be determined, in all four examples, the stakeholder dialogue meets the expectations of both the company and the stakeholders themselves.

\section{CONCLUSION: THE PROCESS DETERMINES THE RESULT}

A stakeholder dialogue can be the beginning of a new "social contract." ${ }^{29}$ Hands-off governments seem to want to leave most of the issue of sustainability to international companies and their primary stakeholders. In this process, much is expected of the so-called reputation mechanism, in which consumers can punish companies that do not conduct business responsibly. Internationally, most governments hardly intend to monitor companies' social responsibility or hold them accountable for this. ${ }^{30}$ In the 1990 s, nongovernmental organizations were increasingly active in calling companies to account-by, for example, furnishing their own codes of conduct-but often lacked the resources to come up with realistic alternatives in the event that companies do not take sustainable business practice seriously. It is true that companies are putting increasingly more effort into codes of conduct and sustainability reports. However, they lack legitimacy and transparency, and also often insight into the exact direction in which they could be/should be guiding their sustainability strategy.

A social playing field of opposing interests and the associated debate is unfolding. In the history of humankind, the creation or adaptation of social contracts has regularly been the subject of intensive conflict, complete with revolutions and even wars. To paraphrase Von Clausewitz: war is the most extreme form of 
debate, with other resources. There is every reason to fear that the tug-of-war concerning socially responsible/sustainable business practice will primarily take the form of a debate. If this is the case, the players will place more importance on being right than on pursuing what is right for society at large. This does not seem particularly fruitful. In contrast, this article has tried to sketch the initial outline of a procedure to resolve this dilemma: by creating a way that a new social contract can be ultimately drawn up by means of a dialogue between the stakeholders. Governments cannot back out of this dialogue. Although they may only be one of the players, it is not a good idea to give governments the role of "secondary" stakeholder or referee. The boundaries of sustainable business practice may still be too vague to assume fixed rules of play, which governments (or other supervisory bodies) could supervise. To an increasing degree, governments are also generally seen as primary stakeholders in the international business society literature. ${ }^{31}$ This seems to be a fair assessment, although it is not always shared by the governments involved.

It is impossible to set out the exact details of a dialogue between the stakeholders-this is precisely what should be the subject of discussion. In our opinion, a just outcome depends on the correct organization of the process.

\section{NOTES}

1. J. Elkington, The Chrysalis Economy: How Citizen CEOs and Corporations Can Fuse Values and Value Creation (Oxford: Capstone, 2001).

2. J. Elkington, Cannibals with Forks: The Triple Bottom Line of 21st Century Business (Oxford: Capstone, 1997).

3. World Resource Institute, United Nations Environment Programme $\&$ World Business Council for Sustainable Development, Tomorrow's Markets: Global Trends and Their Implications for Business (2002), 52.

4. Union of International Associations, Yearbook of International Organizations, 1999.

5. Conference Board, Consumer Expectations on the Social Accountability of Business (New York: The Conference Board, 1999).

6. Investor Responsibility Research Center, Social Issues Service: Shareholder Resolution Database 1973-2000 (IRRC, 2001). 
7. Kinder, Lyenberg, and Domini, Benchmarks. www.kld.com/benchmarks/dsi, 2001.

8. Social Investment Forum, 1999 SRI Trends Report. Zie www.socialinvest.org, 1999.

9. R. van Tulder and A. Kolk, "How Multinationality Affects Ethics: Codes of Conduct in the Sporting Goods Industry," Journal of International Business Studies 32(2) (2001), 267-283.

10. M. Kaptein and J. Wempe, The Balanced Company: A Theory of Corporate Integrity (Oxford: Oxford University Press, 2002).

11. S. Webley, Business Ethics and Company Codes (London: The Institute for Business Ethics, 1998).

12. KPMG and University of Amsterdam, KPMG International Survey of Corporate Sustainability Reporting 2002. (2002).

13. Ibid.

14. SustainAbility, The First International Benchmark Survey of Corporate Sustainability Reporting, 2000. www.sustreport.org/business/report/ trends.html, 2001.

15. Best Practices Sustainable Measures, www.sustreport.org/business/ report/practice.html, 2001; SustainAbility, International Benchmark Survey of Corporate Sustainability Reporting, 2000.

16. Kaptein and Wempe, The Balanced Company.

17. J. Bendell, "Talking for Change? Reflections on Effective Stakeholder Dialogue." A paper for New Academy of Business Innovation Network, 2000; J. Bendell, Terms of Endearment: Business, NGO's and Sustainable Development (Sheffield, U.K.: Greenleaf, 2000).

18. S. Waddock and N. Smith, "Corporate Responsibility Audits: Doing Well by Doing Good," Sloan Management Review (Winter, 2000), 75-83.

19. D. Wheeler and M. Silanpää, The Stakeholder Corporation: A Blueprint for Maximizing Stakeholder Value (London: Pitman, 1997).

20. World Business Council for Sustainable Development, Stakeholder Dialogue: The WBCSD's Approach to Engagement (Switzerland, 2002, 1).

21. KPMG.

22. Kaptein and Wempe, The Balanced Company.

23. See, for example, the Institute for Social and Ethical Accountability, AA 1,000 (London, 1999); and S. Zadek, The Civil Corporation (London: Earthscan, 2001).

24. WBCSD, Stakeholder Dialogue, 1.

25. See also Kaptein and Wempe, The Balanced Company.

26. Zadek, The Civil Corporation. 
27. R. K. Mitchell, B. R. Angle, and D. J. Wood, "Towards a Theory of Stakeholder Identification and Salience: Defining the Principle of Who and What Really Counts," Academy of Management Review 22(4) (1997), 853886.

28. G. Savage, T. Nix, C. Whitehead, and J. Blair, "Strategies for Assessing and Managing Organizational Stakeholders," The Executive 5(2) (1991), 61-75.

29. T. Donaldson and T. Dunfee, Ties That Bind: A Social Contracts Approach to Business Ethics (Boston: Harvard Business School Press, 1999).

30. Social Economic Council, Corporate Social Responsibility (Assen: Royal van Gorcum, 2001).

31. S. Wartick and D. Wood, International Business \& Society (London: Blackwell Business, 1999). 